\title{
Pengaruh Penerapan Prinsip-Prinsip GCG dan Manajemen Risiko Pada Kinerja Keuangan Koperasi di Kabupaten Gianyar
}

\author{
Anak Agung Gede Bagus Putra Wirawan ${ }^{1}$ \\ I Gusti Ayu Made Asri Dwija Putri ${ }^{2}$
}

\author{
${ }^{1}$ Fakultas Ekonomi dan Bisnis Universitas Udayana (Unud), Bali - Indonesia \\ email: putrawiraawan@gmail.com / Telp: 081803690308 \\ ${ }^{2}$ Fakultas Ekonomi dan Bisnis Universitas Udayana (Unud), Bali - Indonesia
}

\begin{abstract}
ABSTRAK
Prinsip-prinsip Good Corporate Governance (GCG) antara lain transparancy, accountability, responsibility, indepedency, dan fairness saat ini harus diterapkan disegala aspek bisnis termasuk koperasi untuk mendorong terciptanya koperasi efisien.Manajemen Risiko disini untuk mengetahui tingkat kesehatan pada koperasi itu sendiri dengan proksi BOPO. Penelitian ini bertujuan untuk mengetahui pengaruh penerapan prinsip-prinsip GCG dan manajemen risiko pada kinerja keuangan yang diukur dengan return on assets pada kinerja keuangan koperasi di Kabupaten Gianyar. Sebanyak 87 koperasi di Kabupaten Gianyar digunakan sampel dalam penelitian. Untuk menentukan sampel menggunakan metode proportionate stratified random sampling. Analisis regresi linier berganda dengan SPSS digunakan teknik analisis data.Hasil pengujian hipotesis menyatakan bahwa prinsip-prinsip GCG berpengaruh positif dan manajemen risiko berpengaruh negatif pada kinerja keuangan koperasi di kabupaten Gianyar.

Kata Kunci: Prinsip-prinsip good corporate governance,manajemen risiko, koperasi, kinerja keuangan
\end{abstract}

\begin{abstract}
The principles of Good Corporate Governance (GCG), among others, transparency, accountability, responsibility, indepedency, and fairness should now be applied in all aspects of the business including cooperatives to encourage the creation of efficient cooperatives. Risk Management is here to know the health level of the cooperative itself with BOPO proxy. This study aims to determine the effect of the application of GCG principles and risk management to financial performance as measured by return on assets in the financial performance of cooperatives in Gianyar regency. A total of 87 cooperatives in Kabupaten Gianyar used samples in the study. To determine the sample using proportionate stratified random sampling method. Multiple linear regression analysis with SPSS used data analysis technique. The result of hypothesis testing stated that GCG principles have positive effect and risk management negatively affect the financial performance of cooperatives in Gianyar regency.

Keywords: Principles of good corporate governance, risk management, cooperatives, financial performance
\end{abstract}

\section{PENDAHULUAN}

Lemahnya penerapan tata kelola didalam perusahaan menjadi pemicu terjadinya

skandal pada bisnis perusahaan, dan menyadarkan orang akan perlunya sistem tata 
kelola yang baik. Mulai saat itu banyak pihak yang berpikir bahwa penerapan corporate governance menjadi sebuah kebutuhan di dalam dunia bisnis yang digunakan sebagai barometer akuntabilitas dari sebuah organisasi bisnis (Dewayanto, 2010).Good governance harus selalu menyesuaikan dengan keaadan, perkembangan, serta system hukum suatu Negara, sehingga praktik Good Governance tiap Negara berbeda (Wibowo, 2010). Tingkat pertumbuhan ekonomi suatu Negara mampu menjadi tolok ukur kemajuan dari Negara itu sendiri (Krismaya Dewi dan Putri, 2014).Negara yang mempunyai tingkat pertumbuhan ekonomi yang baik cenderung karena lembaga keuangannya yang juga baik.Sumber pendanaan masyarakat Indonesia berasal dari lembaga keuangan bank dan non bank. Terdapat beberapa lembaga keuangan yang dapat digunakan khususnya masyarakat di Bali, seperti Bank Umum, Bank Perkreditan Rakyat, Lembaga Perkreditan Desa, dan Koperasi.

Menurut ILO atau Organisasi Buruh Internasional mengatakan bahwa koperasi adalah badan usaha beranggotakan orang seorang atau badan hukum. Dari total 228.000 lebih koperasi yang ada di Indonesia, 81.000 di antaranya telah dibekukan oleh pemerintah karena dinilai tidak memenuhi kriteria yang diperoleh dari situs (diskop.gianyar.go.id). Koperasi yang termasuk dalam sistem pasar akan turut bersaing dalam memberikan pelayanan baik kepada anggota maupun masyarakat sehingga koperasi harus memiliki keunggulan komparatif (Hendar dan Kusnadi, 2005:17). Jumlah koperasi per desember 2016 di kabupaten Gianyar sebanyak 1.219 koperasi, dimana 1.043 koperasi masih aktif dan 176 koperasi 
tidak aktif diperoleh dari situs (diskop.gianyar.go.id). Koperasi yang tidak aktif karena tidak adanya tata kelola yang baik.

Keberhasilan dapat dicapai apabila koperasi sudah memiliki pedoman yang baik dalam mengelola sumber daya yang ada.Good Corporate Governance atau tata kelola perusahaan yang baik merupakan pedoman yang sangat efektif digunakan oleh koperasi untuk meningkatkan daya saing serta akan menciptakan pedoman bagi pengelola koperasi dengan mengelola manajemennya yang baik dengan memperhatikan kepentingan stakholders (stakeholders di lingkungan koperasi). Penerapan good corporate governance diharapkan dapat meningkatkan kinerja serta nilai dari koperasi sendiri dengan memperoleh dana pembiayaan yang lebih murah (Hindistari dan Putri, 2016). Menurut KNKG (2006:5) prinsipprinsip good corporate governance antara laintransparancy (keterbukaan), accountability (akuntabilitas), responsbility (responsibilitas), indepedency (kemandirian), dan fairness (kewajaran dan kesetaraan). Prinsip GCG dibutuhkan agar tercapainya kesinambungan usaha (sustainability) perusahaan dengan memperhatikan stakeholder (KNKG, 2006:5).

Lembaga keuangan sebagian besar sangat memegang peranan penting dalam mendukung perkembangan perekonomian yang ada di Indonesia. Perusahaan akan menghadapi risiko dan tantangan yang semakin sering akan terjadi. Risiko dan tantangan ini dapat terjadi dikarenakan perusahaan ingin mencapai tujuan yang telah ditetapkan, salah satunya mencapai laba maksimal (Ariestya dan Ardhana, 2016).Manajemen risiko merupakan salah satu upaya dalam praktek berkoperasi untuk memperkecil ruang dan kesempatan para 
Anak Agung Gede Bagus Putra Wirawan dan I.G.A.M Asri Dwija Putri.Pengaruh...

pembobol koperasi.Risiko kredit, risiko likuiditas, dan risiko operasional merupakan beberapa risiko yang sering dihadapi institusi perbankan (Darmawi 2011:16-18). Koperasi dalam menjalankan operasinya tentu tidak lepas dari berbagai macam risiko. Salah satu risiko yang sering dihadapi koperasi adalah risiko operasional. Risiko operasional merupakan risiko yang disebabkan oleh kurang berfungsinya proses internal bank, humam eror, kegagalan system teknologi, atau akibat permasalahan eksternal (Majid, 2015). Indikator yang digunakan untuk mengukur risiko operasional adalah menggunakan rasio Beban Operasioanal terhadap Pendapatan Operasional (BOPO). Rasio BOPO digunakan untuk mengukur kemampuan manajemen bank dalam mengendalikan biaya operasional terhadap pendapatan operasional (Nurintan, 2016). BOPO yang tinggi menunjukan tingkat efisiensi yang rendah dari bank dalam menjalankan usahanya sehingga menyebabkan kerugian (Majid, 2015).

Good corporate governance dan kinerja keuangan perusahaan memiliki hubungan yang kuat (Yahya dan Shukeri, 2014). Penerapan sistem Good corporate governance yang baik dapat berpengaruh pada profitabilitas perusahaan (Bistrova dan Lace, 2012).Nilai perusahaan sangat dipengaruhi oleh variabel good corporate governance yang dilakukan dan variabel ini juga berpengaruh terhadap kinerja keuangan (Setyawan dan Putri, 2013). Ukuran profitabilitas pada industri perbankan yang digunakan pada umumnya adalah Return On Asset (ROA) dan Return On Equity (ROE). Penelitian ini menggunakan ukuran ROA sebagai ukuran kinerja keuangan koperasi.Karena ROA berfokus terhadap kemampuan 
perusahaan untuk memperoleh earning dalam operasinya (Sudiyatno dan Suroso, 2010).

Berdasarkan uraian diatas, koperasi merupakan komponen penting bagi perekonomian di Indonesia. Koperasi merupakan bagian dari sistem pasar yang akan bersaing dalam memberikan pelayanan masyarakat. Oleh karena itu untuk menciptakan keunggulan dalam bersaing di dunia perekonomian, koperasi harus menerapkan tata kelola yang baik. Penerapan manajemen risiko dalam koperasi akan mampu membuat bisnis koperasi menjadi sehat dan meminimalisir terjadinya kebangkrutan dalam bisnis koperasi. Oleh karena itu peneliti ingin meneiliti "Pengaruh Penerapan Good Corporate Governance dan Manajemen Risiko pada Kinerja Keuangan Koperasi di Kabupaten Gianyar”.

Berdasarkan latar belakang di atas, masalah yang dapat dirumuskan adalah sebagai berikut: (a) apakah terdapat pengaruh prinsip-prinsip good corporate governance (transparancy, accountability, responsibility, independency, dan fairness)pada kinerja keuangan koperasi di Kabupaten Gianyar ?, (b) Apakah terdapat pengaruh manajemen risiko pada kinerja keuangan koperasi di Kabupaten Gianyar?

Hasil penelitian ini diharapkan akan dapat bermanfaat untuk memberikan tambahan pengetahuan dan pemahaman kepada peneliti lain yang ingin melakukan penelitian dengan topik pengaruh dari prinsip-prinsip good corporate governance dan manajemen risiko untuk dapat memperluas wawasan. Penelitian ini juga dapat digunakan sebagai perbandingan dan penyempurnaan untuk penelitian-penelitian yang telah dilakukan sebelumnya. Begitu pula Penelitian ini 
diharapkan mampu menjadi pedoman dan pertimbangan bagi pihak koperasi bahwa tidak hanya prinsip-prinsip koperasi saja yang ada, namun prinsip-prinsip good corporate governance yang dilakukan secara bersinambungan dalam mengelola koperasi akan mampu meningkatkan kinerja keuangan koperasi tersebut serta mampu menerapkan manajemen risiko di dalam koperasi.

Teori keagenan menekankan pentingnya pemilik perusahan (pemegang saham) menyerahkan pengelolaan perusahaan kepada tenaga-tenaga profesional yang lebih memahami menjalankan bisnis sehari-hari. Semakin besar perusahaan maka akan terjadi pemisahaan antara pemilik dan pengendali perusahaan (Putri dan Ulupui 2017:23). Berdasarkan pada teori agensi, penerepan good corporate governance dapat dijelaskan dengan hubungan antara manajemen (agen) dengan pemilik (principal). Manajemen sebagai agen memiliki tanggung jawab secara moral untuk meningkatkan keuntungan serta kesejahteraan para pemilik (principal) dan sesuai dengan kontrak maka manajemen selaku agen akan memperoleh imbalan dari pemilik. isucorporate governancedapat dipahami dengan menjadikan perspektif teori agensi sebagai dasar atau pedoman. Hubungan asimetri antara pemilik dan pengelola yang diakibatkan oleh teori agensi, dapat dihindari dan diminimalisir dengan membuat suatu kerangka atau konsepGood Corporate Governance yang akan menjadikan perusahaan menjadi lebih sehat sebagai tujuan utama. Menurut Jensen dan Meckling (1976) hubungan kontrak antara pemilik dan manajemen tersebut sejalan dengan agency theory.Dalam Agency theoryterdpat tiga sumsi sifat manusia yang digunakan dalam penjelasaanya. Tiga asumsi sifat manusia antara lain manusia pada umumnya 
mementingkan diri sendiri (self interest), manusia memiliki daya pikir terbatas mengenai persepsi masa mendatang (bounded rationality), dan manusia selalu menghindari resiko (risk averse) (Eisenhardt (1989)).

Konflik kepentingan dapat terjadi dalam organisasi bisnis dikarenakan prinsipal sebagai pihak pemilik tidak dapat selalu memonitor aktivitas manajemen untuk memastikan apakah manajemen telah bekerja sesuai dengan keinginan prinsipal (Pradnyaswari dan Putri, 2015). Menurut Chabacib (2001) dalam Sugiyanto (2011), anggota koperasi memiliki peran ganda disatu sisi sebagai pemilik namun disisi lain sebagai pengguna jasa. Hubungan keagenan dengan organisasi koperasi sangat erat hubungannya antara anggota dengan pengurus koperasi itu sendiri.Dalam koperasi dimana anggota sebagai pihak prinsipal sedangkan pengurus sebagai agen dan dari sanalah masalah keagenan yang mungkin dapat timbul dari pelayanan koperasi.

Teori stewardship mempunyai dasar psikologi dan sosiologi yang telah dirancang dimana para pihak manajemen sebagai steward termotivasi untuk bertindak sesuai keinginan prinsipal, selain itu perilaku steward tidak akan meninggalkan organisasinya sebab steward berusaha mencapai sasaran organisasinya (Riyadi, 2014). Menurut Putri dan Ulupui (2017:24) teori penatalayanan (stewardship theory) mengasumsikan bahwa manajer adalah pelayan yang baik bagi perusahaan.Teori ini dibangun di atas asumsi filosofis mengenai sifat manusia yakni manusia pada hakekatnya dapat dipercaya, mampu bertindak dengan penuh tanggung jawab. 
Anak Agung Gede Bagus Putra Wirawan dan I.G.A.M Asri Dwija Putri.Pengaruh...

Stewardship theory ini timbul berdasarkan kepercayaan pada masingmasing pihak.Pihak yang memberikan kepercayaan disebut principal dan pihak yang diberi kepercayaan adalah steward.Teori ini didasarkan pada pelayan yang memiliki perilaku dimana dia dapat dibentuk agar selalu dapat diajak bekerjasama dalam organisasi, memiliki perilaku kolektif atau berkelompok dengan dedikasi tinggi daripada individunya dan selalu bersedia untuk melayani(Wijaya dan Sudarma, 2015).

Kajian atas corporate governance mulai disinggung pertama kalinya oleh Berle dan Means pada tahun 1932 ketika membuat sebuah buku yang menganalisis terpisahnya kepemilikan saham (ownership) dan kontrol (Mintara, 2008).Penerapan prinsip-prinsip good corporate governance dalam dunia usaha saat ini merupakan suatu tuntutan agar perusahaan - perusahaan tersebut tetap dapat eksis dalam persaingan global.Komite Nasional Kebijakan Governance (2006) mengungkapkan setiap perusahaan harus memastikan bahwa prinsipprinsip good corporate governance diterapkan pada setiap aspek bisnis dan di semua jajaran perusahaan.Dalam melaksanakan kegiatan usahanya organisasi bisnis harus menganut kelima prinsip-prinsip yang telah ditetapkan oleh KNKG (Budiarti, 2010) dalam (Pradnyaswari dan Putri, 2015).Kelima prinsip-prinsip tersebut meliputi tranparancy memiliki arti bahwa perlunya keterbukaan dalam menyediakan informasi yang bersifat material dan material oleh manajemen, accountability berarti kejelasan struktur, fungsi maupun sistem sangat penting di dalam perusahaan. Apabila prinsip ini dijalankan dengan efektif, maka akan ada kejelasan akan fungsi, hak dan kewajiban antara pemegang saham, dewan 
komisaris, dan dewan direksi. perusahaan itu sendiri, responsibility memiliki arti dengan diterapkan prinsip ini, maka perusahaan akan sadar akan tanggung jawab perusahaan kepada shareholder maupun stakeholdernya, Indepedency berarti dengan adanya prinsip ini akan membuat perusahaan dikelola dengan profesional tanpa adanya intervensi dari pihak luar, fairness memiliki arti dengan diterapkan prinsip ini maka perusahaan akan dituntut secara adil untuk memenuhi hak stakeholder sesuai peraturan yang berlaku. Prinsip-prinsip GCG digunakan untuk mengukur sejauh mana prinsip GCG telah diterapkan dalam manajerial perusahaan (Arifin, 2005).

Manajemen risiko adalah suatu proses untuk mengidentifikasi, mengukur, memantau, dan mengendalikan risiko yang timbul serta mengambil langkahlangkah perbaikan yan dapat menyesuaikan risiko pada tingkat yang dapat diterima, sehingga bank memiliki komposisi portofolio dengan risk dan return yang seimbang ( Hanafi , 2006).Suatu sistem pengelolaan risiko yang dihadapi oleh organisasi secara komperhensif dengan tujuan untuk meningkatkan nilai perusahaan juga dapat didefinisikan sebagai manajemen risiko (Nurintan, 2016). Risiko yang wajib dinilai terdiri atas 8 (delapan) jenis risiko yaitu risiko kredit, risiko pasar, risiko operasional, risiko likuiditas, risiko hukum, risiko strategik, risiko kepatuhan, dan risiko reputasi (Bank Indonesia: SEBI No.13/24/DPNP:2011). Ada beberapa indikator yang dapat diukur dari delapan risiko tersebut seperti risiko kredit, risiko pasar, risiko lukuiditas dan risiko operasional. Menurut Ali (2006), risiko operasional adalah risiko terjadinya kerugian bagi bank yang diakibatkan oleh ketidakcukupan atau kegagalan proses 
didalam manajemen bank, sumber daya alam manusia, dan sistem. Risiko kerugian itu dapat pula terjadi sebagai akibat faktor-faktor diluar bank. Risiko operasional pada dasarnya terikat dengan sejumlah masalah yang bersumber dari terjadinya kegagalan dalam proses internal manajemen bank. Berdasarkan SEBI No.6/23/2004, nilai maksimal BOPO adalah sebesar 94\%.Jika suatu bank memiliki nilai BOPO lebih dari ketentuan yang telah ditentukan maka bank tersebut masuk dalam kategori tidak efisien, karena semakin tinggi BOPO berarti peningkatan biaya operasionalnya semakin besar daripada peningkatan pendapatan operasionalnya sehingga laba yang diperoleh turun dan ROA maupun ROE menurun.

Menurut Waddock dan Graves (1997) kinerja keuangan perusahaan diukur dengan menggunakan tiga variabel akuntansi yaitu return on asset, return on equity, dan return on sales. Return On Assets (ROA)adalah kemampuan modal yang diinvestasikan ke dalam semua aktiva perusahaan untuk dapat menghasilkan laba (Prasnanugraha, 2007). ROA menunjukan seberapa banyak laba bersih yang dapat diperoleh dari keseluruhan aset yang dimiliki oleh perusahaan (Ermawati, 2014).ROA digunakan untuk mengukur efektifitas perusahaan didalam menghasilkan keuntungan dengan memanfaatkan aktiva yang dimilikinya (Puspitasari, 2009).ROA merupakan ukuran efektivitas perusahaan dalam mendapatkan laba atau keuntungan dengan memaksimalkan aset yang dimiliki.Tingkat efektifitas perusahaan dapat dilihat dengan semakin meningkatnya ROA perusahaan tersebut, karena besarnya keuntungan atau laba yang dihasilkan perusahaan akan mememngaruhi tingkat ROA itu sendiri 
(Prasnanugraha, 2007). Keuntungan menggunakan ROA adalah pengukuran yang komprehensif dimana semua yang mempengaruhi laporan keuangan dapat tercermin (Setyawan dan Putri, 2013).

Secara sederhana prinsip transparansi merupakan keterbukaan informasi dalam laporan perusahaan.Menurut Haque dan Kirkpatrick (2008) sangat penting bagi perusahaan untuk membuat informasi keuangan dan non-keuangan yang mudah diakses oleh orang luar agar orang dapat membuat keputusan. Perusahaan akan dituntut lebih akurat dan tepat waktu menyajikan informasi kepada segenap stakeholdernya, sehingga kecurangan yang terjadi di dalam perusahaan dapat diminimalisir. Informasi yang diungkapkan antara lain keadaan keuangan, kinerja keuangan, kepemilikan dan pengelolaan perusahaan. Apabila dalam organisasi menerapkan prinsip tranparancy ini, maka para stakeholder akan mempunyai kepercayaan terhadap organisasi tersebut sehingga akan lebih baik. Akuntabilitas merupakan kejelasan struktur, fungsi dan sistem dalam elemen perusahaan. Menurut Widodo (2011) dalam Martha (2014) accountability merupakan persyaratan mendasar untuk mencegah penyalahgunaan kewenangan yang didelegasikan dan menjamin kewenangan diarahkan pada pencapaian-pencapaian tujuan nasional yang diterima secara luas dengan tingkat efisiensi, efektifitas, dan kejujuran.Menurut hasil penelitian Suci (2013) responsibility secara parsial berpengaruh terhadap kinerja perusahaan.Indepedency adalahsuatu keadaan dimana perusahaan dikelola secara profesional tanpa benturan kepentingan dan pengaruh atau tekanan dari pihak manapun yang tidak sesuai dengan peraturan perundang-undangan yang berlaku dan prinsip-prinsip korporasi yang sehat (Suci, 
2013). Prinsip ini mensyaratkan agar perusahaan dikelola tanpa adanya benturan dan intervensi dari pihak manapun yang tidak sesuai dengan peraturan - peraturan yang berlaku. Fairness menuntut adanya perlakuan yang adil dalam memenuhi hak stakeholder sesuai dengan perundangan yang berlaku.Menurut penelitian Rahmatika dkk.(2015) menyatakan pengaruh antara kewajaran terhadap kinerja keuangan menunjukan koefisien positif sebesar 0.096, hal ini menunjukkan bahwa kewajaran berpengaruh signifikan terhadap kinerja keuangan.Dengan demikian hasil penelitian ini menunjukkan bahwa kewajaran berpengaruh terhadap kinerja keuangan. Hal tersebut sejalan dengan peneliti Krismaya Dewi dan Putri (2014) yang menyatakan prinsip - prinsip good corporate governance berpengaruh terhadap kinerja keuangan LPD di Kabupaten Gianyar Bali.Serta didukung oleh penelitian Ridwan (2008) yang menyatakan bahwa prinsip GCG berpengaruh terhadap kinerja keuangan.

$\mathrm{H}_{1}$ : Prinsip-prinsip good corporate governance berpengaruh positif pada kinerja keuangan koperasi di Kabupaten Gianyar

Manajemen risiko bisa terjadi disetiap perusahaan.Manajemen risiko bisa menjadi penghambat dalam kelangsungan perusahaan.Manajemen risiko dalam penelitian ini diproksikan pada manajemen risiko operasional dalam koperasi yang ada di Kabupaten Gianyar yang diukur menggunakan BOPO.Koperasi merupakan miniatur dari sebuah bank.Koperasi tidak terlepas dari berbagai macam risiko yang terjadi.Banyaknya koperasi di Kabupaten Gianyar yang tidak aktif juga harus diperhitungkan dengan berbagai macam risiko.Risiko operasional dapat digunakan untuk mengetahui kesehatan dari koperasi itu sendiri.Biaya operasional digunakan untuk mengukur tingkat efisiensi dan kemampuan bank 
dalam melakukan kegiatan operasionalnya.Semakin kecil BOPO menunjukkan semakin efisien bank dalam menjalankan aktivitas usahanya sehingga semakin baik bank tersebut. Dengan kata lain, rasio BOPO berpengaruh negatif terhadap ROA (Nurintan, 2016). Fatmawati (2013) melakukan penelitian tentang "Pengaruh Risiko Kredit dan Efisiensi Operasional Terhadap Kinerja Bank (Studi Empirik pada Bank yang Terdaftar di Bursa Efek Indonesia)”.Dalam penelitian ini menggunakan variabel CAR, LDR dan BOPO.Hasil penelitian ini menunjukan bahwa terdapat perbedaan pengaruh $\mathrm{CAR}$, LDR dan BOPO terhadap kinerja keuangan (ROA) pada bank umum.Hal itu sejalan dengan penelitian Nurintan (2016) yang menyatakan BOPO tidak berpengaruh signifikan terhadap kinerja keuangan perbankan (ROA).

$\mathrm{H}_{2}$ : Manajemen Risiko berpengaruh negatif pada kinerja keuangan koperasi di Kabupaten Gianyar

\section{METODE PENELITIAN}

Koperasi di Kabupaten Gianyar menjadi lokasi dalam penelitian ini.Metode pengumpulan data yang digunakan dengan memberikan kuisioner dan mencari laporan keuangan hasil Rapat Anggota Tahunan (RAT) koperasi yang dijadikan sebagai sampel penelitian tahun 2013-2015.Data kuantitatif dalam penelitian ini berupa angka yang tertera dalam laporan keuangan koperasi di Kabupaten Gianyar untuk mencari manajemen risiko dan kinerja keuangan.Data kualitatif dalam penelitian ini yaitu deskripsi responden penelitian tentang prinsip-prinsip GCG pada koperasi di Kabupaten Gianyar.Data primer dalam penelitian ini adalah skor deskripsi responden penelitian yang tertera pada lembar kuisioner dan data sekunder yang merupakan data yang diperoleh dari laporan keuangan yang 
Anak Agung Gede Bagus Putra Wirawan dan I.G.A.M Asri Dwija Putri.Pengaruh...

dipertanggungjawabkan pada saat RAT masing-masing koperasi di Kabupaten Gianyar periode 2013-2015. Variabel prinsip-prinsip GCG merupakan variabel independen diukur dengan kuisioner berupa pertanyaan yang berhubungan dengan variabel tranparancy, accountability, responsibility, indepedency, dan fairness, sedangkan variabel manajemen risiko merupakan variabel independen diukur dengan Beban Operasional Pendapatan Operasional (BOPO), dan variabel kinerja keuangan sebagai variabel dependen diukur dengan return on assets.

Pengumpulan data dilakukan melalui penyebaran kuisioner dan mendokumentasikan data mengenai laporan keuangan koperasi di Kabupaten Gianyar yang dipertanggungjawabkan kepada anggota ketika rapat angota tahunan. Variabel prinsip-prinsip GCG diukur dengan (1) Tranparancy atau keterbukaan dengan 4 (empat) pertanyaan antara lain mengenai sistem akuntansi dalam perusahaan, pengembangan teknologi informasi manajemen dan manajemen risiko, serta publikasi informasi keuangan dan informasi lain yang material mengenai perusahaan, (2) accountability diukur dengan 4 (empat) pertanyaan mengenai komite audit, peran dan fungsi auditor internal dan eksternal, serta sistem penilaian kinerja dalam perusahaan, (3) responsibility atau pertanggungjawaban diukur dengan 4 (empat) pertanyaan mengenai tanggung jawab sosial perusahaan, profesionalisme dan etika bisnis, serta lingkungan bisnis dalam perusahaan apakah sudah cukup baik atau belum, (4) indepedency diukur dengan 4 (empat) pertanyaan mengenai penggunaan tenaga ahli dalam perusahaan, pengaruh pihak luar, benturan kepentingan, dan aktivitas perusahaan, (5) fairness diukur dengan 4 (empat) pertanyaan mengenai aturan perusahaan 
untuk melindungi kepentingan pemegang saham, peran dan tanggung jawab dewan komisaris dan manajemen, serta kewajaran dalam pengungkapan sistem informasi.

Manajemen risiko dalam hal ini penelitian ini diwakili oleh manajemen risiko operasional.Beban Operasional Pendapatan Operasional (BOPO) merupakan rasio usaha yang membandingkan antara biaya operasional pendapatan operasional guna mendapatkan gambaran mengenai kemampuan dari pihak manajemen lembaga keuangan dalam mengendalikan biaya operasional pendapatan operasional (Almilia dan Herdiningtyas, 2005).Penerapan manajemen risiko operasional merupakan serangkaian prosedur dan metodelogi yang dilakukan bank sehingga dapat meminimalkan terjadinya risio operasional.Yuliani (2007) menggunakan rasio BOPO utuk mengukur kemampuan manajemen bank dalam mengendalikan biaya operasional terhadap terhadap pendapatan operasional.Berdasarkan SEBI No.13/30/2011, BOPO dirumuskan dengan membandingkan biaya operasional terhadap pendapatan operasional.

Rasio BOPO $=\frac{\text { Beban Operasional }}{\text { Pendapatan Operasional }} \times 100 \%$

Variabel terikat dalam penelitian ini adalah kinerja keuangan yang dapat diukur dengan return on assets. ROA dimaksudkan untuk mengukur kemampuan perusahaan dengan keseluruhan dana yang ditanamkan dalam aktiva yang digunakan untuk operasional perusahaan tersebut agar dapat menghasilkan keuntungan, dengan mengetahui rasio ini akan dapat diketahui apakah perusahaan efisien dalam memanfaatkan aktivanya dalam kegiatan operasional perusahaan. ROA digunakan untuku membandingkan antara volume hasil usaha yang 
diperoleh dengan aset koperasi untuk menganalisis kinerja keuangan koperasi pada tahun yang diteliti.ROA dapat dirumuskan sebagai berikut.

ROA $=\frac{\text { Sisa Hasil Usaha }}{\text { Total Asset }} \times 100 \%$

Seluruh koperasi di Kabupaten Gianyar yang tergolong aktif dan menyetorkan laporan pertanggungjawaban hasil RAT menjadi populasi dalam penelitian ini. Koperasi yang masih tercatat aktif dan menyetorkan laporan pertanggungjawaban hasil RAT tahun 2016 berjumlah 683 koperasi yang tersebar di tujuh kecamatan di Kabupaten Gianyar. Metode proportionate stratified random sampling digunakan sebagai metode penentuan sampel dalam penelitian ini, jadi untuk menentukan proporsi sampelnya akan menggunakan rumus Slovin. Berdasarkan rumus slovin maka sampel diambil sebanyak 87 koperasi di Kabupaten Gianyar dengan 1 responden.

Sebelum melakukan analisis data terlebih dahulu diawali dilakukan pengujian terhadap instrumen penelitian yaitu dengan melaksanakan uji validitas dan uji reliabilitas.Instrumen yang dapat digunakan untuk penelitian adalah instrumen yang dinyatajkan valid dan reliabel. Instrumen dapat dinyatakan valid apabila nilai koefisien pearson correlation besarnya > 0,3 (Ghozali, 2012:54-55). Sedangkan reliabilitas instrumen diukur menggunakan uji statistik Cronbach Alpha $(\alpha)$. Jika nilai koefisien Cronbach Alpha $(\alpha)>0,70$ maka instrumen atau konstruk dapat dikatakan reliabel (Ghozali, 2012:47).

Mengetahui pengaruh prinsip-prinsip GCG dan manajemen risiko pada kinerja keuangan koperasi digunakan teknik analisis regresi linier berganda.Namun, sebelum digunakan model regresi linier berganda terlebih 
dahulu dilakukan pengujian asumsi klasik, analisis statistik deskriptif dan uji goodness of fit agar tidak terjadi bias dalam melakukan pengujian. Untuk pengujian asumsi klasik diawali dengan uji normalitas dimana apabila nilai Asymp.Sig (2-tailed) $>\alpha(0,05)$ maka dapat disimpulakan data terdistribusi normal (Ghozali, 2012:164). Data bebas dari multikoloniertitas apabila nilai tolerance $\geq$ 0,10 atau sama dengan nilai VIF $\leq 10$ (Ghozali, 2012:106). Uji glejser digunakan untuk dapat mendeteksi adanya heteroskedastisitas dalam data penelitian, dapat dilihat apabila probabilitas signifikansinya $>0,05$ jadi dapat disimpulkan bahwa model regresi tidak mengandung gejala heteroskedastisitas (Ghozali, 2012:141).

Setelah dilakukan uji asumsi klasik, selanjutnya analisis statistik deskriptif dengan melihat dari nilai mean, standar deviasi, varian, nilai tertinggi dan nilai terendah dari data (Ghozali, 2012:19). Data yang dianalisis adalah prinsip-prinsip GCG dan manajemen risiko serta kinerja keuangan.Uji goodness of fitnya dilakukan untuk menguji ketepatan fungsi regresi sampel dalam menaksir nilai aktual (Ghozali, 2012:97). Bila dilihat secara statistik yaitu dari nilai Adjusted R2 dalam uji koefisien determinasi nilai dari koefisien determinasi antara 0-1, apabila nilai koefisien determinasi tinggi atau mendekati atau sama dengan 1 berarti variabel dependen mampu sepenuhnya menjelaskan variabel dependen begitupula sebaliknya. Dalam uji kelayakan model jika tingkat signifikansi $\mathrm{F}$ lebih kecil $\alpha=$ 0,050 maka H0 ditolak, dan sebaliknya jika tingkat signifikansi $\mathrm{F}$ lebih besar sama dengan $\alpha=0,05$ maka H0 diterima (Ghozali, 2012:98). Untuk menguji hipotesis dilakukan uji statistik $\mathrm{t}$ dengan membandingkan tingkat signifikansi masingmasing variabel bebas dengan $\alpha=0,050$. Apabila tingkat signifikansi t lebih kecil 
dari $\alpha=0,050$ maka H0 ditolak, sebaliknya jika tingkat signifikan t lebih dari sama dengan $\alpha=0,050$ maka H0 diterima (Ghozali, 2012:98). Regresi linier berganda melalui program komputer SPSS merupakan teknik analisis dalam penelitian ini.Analisis regresi linier berganda digunakan karena penelitian ini menggunakan lebih dari satu variabel independen.Adapun rumus regresinya adalah sebagai berikut.

$\mathrm{Y}=\alpha+\beta_{1} \mathrm{X}_{1}+\beta_{2} \mathrm{X}_{2}+\mathrm{e}$

Keterangan:

$\mathrm{Y} \quad=$ Variabel terikat ( kinerja keuangan)

A $\quad=$ Konstanta

$\beta_{1}, \beta_{2}=$ Koefisien regresi untuk $X_{1}, X_{2}$

$\mathrm{X}_{\mathrm{I}} \quad=$ Variabel bebas (prinsip - prinsip good corporate governance)

$\mathrm{X}_{2} \quad=$ Variabel bebas (manajemen risiko)

$\mathrm{E} \quad=$ Standar error

\section{HASIL DAN PEMBAHASAN}

Teknik analisis data diawali dengan pengujian instrumen penelitian yaitu menguji validitas dan reliabilitas instrumen penelitian. Hal ini dilakukan mengingat kuesioner merupakan instrumen yang penting dalam penelitian ini.Instrumen yang valid dan reliabel merupakan syarat mutlak untuk mendapatkan hasil penelitian yang relevan.Sebelum kuesioner penelitian disebarkan, terlebih dahulu dilakukan uji validitas dan reliabilitas untuk menguji kuesioner penelitian. Apabila korelasi antara masing-masing indikator terhadap total konstruk menunjukkan hasil yang signifikan maka dapat disimpulkan indikator pertanyaan dalam kuesioner dinyatakan valid (Ghozali, 2012:54-55). Hasil uji validitas akan tersaji dalam Tabel 1. 
Tabel 1.

Hasil Uji Validitas

\begin{tabular}{ccc}
\hline No & Variabel & Nilai Pearson Correlation \\
\hline 1 & Prinsip-prinsip GCG & 0,935
\end{tabular}

Sumber: Data diolah, 2017

Hasil yang tertera dalam Tabel 1 yaitu dinyatakan bahwa hasil korelasi skor faktor dengan skor total (Pearson Correlation) bernilai positif $>0,30$ maka dapat ditarik kesimpulan bahwa instrumen penelitian ini memiliki validitas konstruksi yang baik.

Uji statistik Cronbach Alpha $(\alpha)$ digunakan untuk mengukur reliabilitas dari penelitian. Jika nilai Cronbach Alpha $(\alpha)>0,70$ maka konstruk atau variabel dapat dinyatakan reliabel atau handal untuk dijadikan sebagai variabel penelitian. Dari pengujian reliabilitas diperoleh hasil koefisien cronbach alpha $(\alpha)$ variabel prinsip-prinsip GCG 0,986. Dari hasil pengujian reliabilitas tersebut dapat dinyatakan bahwa semua nilai Cronbach Alpha $(\alpha)$ tiap variabel $>0,70$ maka disimpulkan bahwa instrumen dalam penelitian ini memiliki konstruk atau variabel yang reliabel atau handal.

Uji statistik non-parametrik Kolmogorov-Smirnov (K-S) digunakan dalam pengujian normalitas residual.Data dapat dikatakan berdistribusi normal apabila Asymp.Sig (2-tailed) $>\alpha=0,05$ (Ghozali, 2012:164). Berdasarkan hasil uji normalitas menunjukkan Nilai Asymp. Sig. (2-tailed) yaitu 0,200 lebih besar dari tingkat signifikansi 0,05 , yang berarti data yang digunakan pada penelitian ini telah berdistribusi normal. 
Anak Agung Gede Bagus Putra Wirawan dan I.G.A.M Asri Dwija Putri.Pengaruh...

Agar dapat menemukan adanya korelasi antara variabel independen dalam model regresi dilakukan uji multikolonieritas (Ghozali, 2012:105).Uji multikolinearitas bertujuan untuk menguji apakah model regresi ditemukan adanya korelasi antara variabel bebas. Hasil uji ini dapat dilihat bahwa nilai tolerance pada masing-masing variabel lebih besar dari 0,1 , demikian pula dengan nilai VIF masing-masing variabel yang lebih kecil dari 10, sehingga ditarik kesimpulan bahwa tidak terdapat multikolonieritas antara varibel indepednen dalam penelitian ini.

Uji Glejser digunakan untuk mendeteksi ada tidaknya gejala heteroskedastisitas dalam penelitian ini, model regresi tidak mengandung heteroskedastisitas yaitu apabila probabilitas signifikansinya di atas tingkat kepercayaan 5\% (Ghozali, 2012:141).Berdasarkan hasil uji heteroskedastisitas memperoleh hasil nilai Sig. variabel independen > 5\% maka dapat ditarik kesimpulan bahwa model regresi yang digunakan penelitian ini tidak mengandung gejala heteroskedastisitas.

Pemberiaan deskripsi variabel dalam penelitian ini yang dilihat dari nilai rata - rata, standar deviasi, varian, nilai maksimum dan nilai minimum digunakan analisis statistik deskriptif (Ghozali, 2012:19).Data yang dianalisis adalah prinsipprinsip GCG, manajemen risiko serta kinerja keuangan.Hasil analisis statistik deskriptif penelitian ini dinyatakan dalam Tabel 2.berikut. 
Tabel 2.

Hasil Uji Statistik Deskriptif Variabel Independen dan Dependen

\begin{tabular}{cccccc}
\hline & N & Minimum & Maximum & Mean & $\begin{array}{c}\text { Std. } \\
\text { Deviation }\end{array}$ \\
\hline Kinerja Keuangan (Y) & 87 & .0098 & .5338 & .150541 & .1321019 \\
Prinsip-prinsip GCG (X1) & 87 & 20.0000 & 77.0135 & 55.613629 & 16.77190 \\
Manajemen Risiko (X2) & 87 & .4100 & .8700 & .701606 & 77 \\
Valid & 87 & & & & .0862669 \\
\hline Sumber: Daladion 2017 & & & & &
\end{tabular}

Sumber: Datadiolah, 2017

Berdasarkan hasil olahan SPSS dalam Tabel 2 statistik deskriptif untuk variabel independen yaitu prinsip-prinsip good corporate governance yang diukur melalui kuesioner dan manajemen risiko diukur dengan BOPO memaparkan nilai minimum, nilai maksimum, rata-rata dan standar deviasi dengan jumlah 87 kasus. Variabel Prinsip-prinsip Good Corporate Governance memiliki nilai minimum sebesar 20,0000 nilai maksimum 77,0135 rata-rata penerapan variabel 55,613629 dengan penyimpangan nilai variabel terhadap nilai rata-ratanya yang ditunjukkan melalui standar deviasi yaitu sebesar 16,7719077. Variabel Manajemen Risiko memiliki nilai minimum sebesar 0,4100 nilai maksimum 0,8700 rata-rata penerapan variabel 0,701606 dengan penyimpangan nilai variabel terhadap nilai rata-ratanya yang ditunjukan melalui standar deviasi yaitu sebesar 0,0862669. Hal ini menunjukan bahwa nilai standar deviasi lebih kecil dibandingkan dengan nila rata-rata, yang berarti bahwa Manajemen Risiko yang diproksikan dengan BOPO memiliki fluktuasi yang kecil. Kinerja Keuangan memiliki nilai minimum sebesar 0,0098 nilai maksimum 0,5338 rata-rata penerapan variabel 0,150541 dengan penyimpangan nilai variabel terhadap nilai rata-ratanya yang ditunjukkan melalui standar deviasi yaitu sebesar 0,1321019. 
Anak Agung Gede Bagus Putra Wirawan dan I.G.A.M Asri Dwija Putri.Pengaruh...

Berdasarkan hasil output SPSS model summary yang dinyatakan dalam Tabel 4 untuk dapat mengetahui seberapa besar prinsip-prinsip GCG dan manajemen risiko memengaruhi kinerja keuangan, dapat dilihat dari nilai koefisien adjusted R2 adalah 0,225 berarti 22,5\% variasi kinerja keuangan dapat dijelaskan oleh variasi prinsip-prinsip GCG dan manajemen risiko. Sedangkan sisanya 77,5\% (100\% - 22,5\%) dijelaskan oleh faktor lain diluar model. Tabel 5 menjelaskan bahwa nilai $\mathrm{F}$ sebesar 13,464 dengan probabilitas 0.000. Karena probabilitas $<0,05$ maka prinsip-prinsip GCG dan manajemen risiko dapat diprediksi oleh model regresi atau dapat dikatakan bahwa prinsip-prinsip GCG dan manajemen risiko secara simultan berpengaruh pada kinerja keuangan koperasi di Kabupaten Gianyar.

Tabel 3.

Rekapitulasi Hasil Analisis Regresi Linier Berganda

\begin{tabular}{|c|c|c|c|c|c|c|}
\hline \multirow[t]{2}{*}{ Model } & & \multicolumn{2}{|c|}{$\begin{array}{l}\text { Unstandardized } \\
\text { Coefficients }\end{array}$} & \multirow{2}{*}{$\begin{array}{c}\begin{array}{c}\text { Standardized } \\
\text { Coefficients }\end{array} \\
\text { Beta }\end{array}$} & \multirow[t]{2}{*}{$\mathbf{t}$} & \multirow[t]{2}{*}{ Sig. } \\
\hline & & B & $\begin{array}{c}\text { Std. } \\
\text { Error }\end{array}$ & & & \\
\hline & (Constant) & .232 & .129 & & 1.802 & .075 \\
\hline & $\begin{array}{l}\text { Prinsip- } \\
\text { prinsip Good } \\
\text { Corporate }\end{array}$ & .003 & .001 & .371 & 3.705 & .000 \\
\hline & $\begin{array}{l}\text { Governance } \\
\text { Manajemen } \\
\text { Risiko }\end{array}$ & -0.348 & 0,153 & -.227 & -2.271 & .026 \\
\hline
\end{tabular}

Sumber: Data diolah, 2017

Berdasarkan Tabel 3 menunjukan hasil analisis hipotesis setelah diuji untuk hipotesis pertama prinsip-prinsip good corporate governance berpengaruh positif pada kinerja keuangan koperasi di Kabupaten Gianyar.Hasil uji t menunjukan nilai $\mathrm{t}_{\text {hitung }}$ untuk variabel prinsip-prinsip good corporate governance adalah 3,705 dengan signifikansi 0,000 . Karena $t_{\text {hitung }}$ lebih besar dari $t_{\text {tabel }}(1,671)$ dan 
signifikansi $\mathrm{t} \leq \alpha=0,05$ maka hipotesis diterima yang berarti bahwa prinsipprinsip good corporate governance berpengaruh positif pada kinerja keuangan.

Berdasarkan Tabel 3 menunjukan hasil analisis hipotesis setelah diuji untuk hipotesis kedua manajemen risiko berpengaruh negatif pada kinerja keuangan koperasi di Kabupaten Gianyar.Hasil uji t menunjukan nilai $t_{\text {hitung }}$ untuk variabel manajemen risiko adalah $-2,271$ dengan signifikansi 0,026 . Karena $t_{\text {hitung }}$ lebih kecil dari $-\mathrm{t}_{\text {tabel }}(-1,671)$ dan signifikansi $\mathrm{t} \leq \alpha=0,05$ maka hipotesis diterima yang berarti bahwa manajemen risiko berpengaruh negatif dan pada kinerja keuangan.

\section{SIMPULAN}

Berdasarkan pada hasil analisis dan data dan pembahasan pada bab sebelumnya mengenai pengaruh prinsip-prinsip good corporate governance dan manajemen risiko pada kinerja keuangan koperasi di Kabupaten Gianyatr, maka dapat dapat disimpulkan beberapa hal antara lain. Prinsip-prinsip Good Corporate Governance (transparancy, accountability, responsibility, indepedency dan fairness) berpengaruh positif pada kinerja keuangan koperasi di Kabupaten Gianyar. Hal ini berarti bahwa prinsip-prinsip GCG meningkatkan kinerja keuangan koperasi di Kabupaten Gianyar sehingga koperasi akan melaksanakan kinerja keuangannya dengan baik dan sesuai prosedur koperasi. Manajemen Risiko berpengaruh negatif pada kinerja keuangan koperasi di kabupaten Gianyar.Berdasarkan data BOPO koperasi di Kabupaten Gianyar periode 2013-2015 bahwa rasio BOPO rata-rata dibawah 90\%.Hal ini dapat diartikan bahwa koperasi yang ada di Kabupaten Gianyar sudah efisien dalam melaksanakan kegiatannya. 
Anak Agung Gede Bagus Putra Wirawan dan I.G.A.M Asri Dwija Putri.Pengaruh...

Berdasarkan simpulan di atas, maka dapat dinyatakan beberapa saran sebagai berikut.Koperasi memiliki peranan yang sangat penting dalam perekonomian di Indonesia khususnya di Bali.Selain mempertimbangkan prinsip koperasi dalam kegiatan operasionalnya, diharapkan koperasi mempertimbangkan pula pengaruh prinsip-prinsip good corporate governance dan manajemen risiko yang dapat meningkatkan kinerja keuangannya.Maka disarankan kepada seluruh koperasi di seluruh Bali juga menerapkan prinsip good corporate governance dan manajemen risiko khususnya BOPO dengan baik untuk kelangsungan koperasi kedepannya.Untuk penelitian selanjutnya diharapkan untuk memperluas objek dan menambah variabel penelitian seperti komitmen organisasi, struktur modal dan untuk mengukur kinerja tidak hanya pada aspek keuangan saja tetapi juga mengukur pada aspek non keuangan.Sampel yang digunakan dalam penelitian ini hanya pada koperasi yang ada pada Kabupaten Gianyar, sehingga belum mampu mempresentasikan semua koperasi yang ada di Bali. Untuk penelitian selanjutnya diharapkan memilih sampel koperasi yang berada di Kabupaten/Kota lain di Bali supaya lebih dapat menggambarkan pengaruh dari variabel-variabel penelitian ini pada koperasi di Bali.

\section{REFERENSI}

Ariestya, Putu Yutika. dan Ardiana, Putu Agus. 2016. Implementasi Good Corporate Governance pada Kinerja Perusahaan Sektor Keuangan dengan Manajemen Risiko sebagai Variabel Intervening. Jurnal Fakultas Ekonomi dan Bisnis Universitas Udayana.

Bistrova, J., and Lace, N. 2012.Corporate Governance Influence on Firms' Financial Performance in CEE Countries.In 7th International Scientific Conference Business and Management-2012, Vilnius, not published. 
Brigham, Eugene F. dan Houston. 2006. Fundamental of Financial Management : Dasar-Dasar Manajemen Keuangan. Edisi 10. Jakarta: Salemba Empat.

Budiarti, I. 2010. Penerapan Prinsip-prinsip Good Corporate Governance Pada Dunia Perbankan. JurnalManajemen, 8.

Dewayanto, T. 2010. Pengaruh Mekanisme Good Corporate Governance terhadap Kinerja Perbankan Nasional (Studi Pada Perusahaan Perbankan yang Terdaftar di Bursa Efek Indonesia Periode 2006-2008).Jurnal Fokus Ekonomi, 5(2):h:104-123.

Dietrich, Andreas and Gabrielle Wanzenried. 2009. What Determines the Profitability of Commercial Banks? New Evidence from Switzerland.Journal.

Eisenhardt, Kathleem. M. 1989. Agency Theory: An Assesment and Review. Academy of management Review, 14, hal 57-74.

Farida, Y. N., Prasetyo, Y., dan Herwiyanti, E. 2010. Pengaruh Penerapan Corporate Governance terhadap Timbulnya Earnings Management dalam Menilai Kinerja Keuangan pada Perusahaan Perbankan di Indonesia.Jurnal Bisnis dan Akuntansi, 12(2): h.69-80.

Fathi, Jouini. 2013. Corporate Governance and The Level of Financial Disclosure by Tunisian Firm. Journal of Business Studies Quarterly, 4(3).

Fatmawati, Asih. 2013. Pengaruh Risiko Kredit dan Efisiensi OperasionalTerhadap Kinerja Bank (Studi Empirik pada Bank yang Terdaftar di Bursa Efek Indonesia). Jurnal Organisasi Manajemen. Volume 9,Nomor 1, Maret 2013, 73-86.

Ferdiana, N. 2012.Pengaruh Good Corporate Governance Terhadap Kinerja Keuangan Perusahaan Pertambangan Di BEI.Jurnal Ilmiah Mahasiswa Akuntansi, 1(2), 11-15.

Ghozali, H. Imam. 2012. Aplikasi Analisis Multivariate dengan Program IBM SPSS. Edisi Enam.Semarang: Universitas Diponegoro.

Haque, F., Arun, T., and Kirkpatrick, C. 2008. Corporate Governance and Capital Markets: A conceptual framework. White paper, Heriot-Watt University.

Hanley, N., and Shogren, J.F., White, B, 1997. Environmental Economics in Theory and Practice. Mc Millan, New York. 
Hendra Karjaya, IW. dan Sisdyani. 2014. Pengaruh Tingkat Pengungkapan CSR dan Mekanisme GCG pada Kinerja Keuangan Perusahaan Pertambangan.

Hollensbe, E., Wookey, C., Loughlin, H., George, G., \& Nichols, V. 2014. Organizations with purpose. Academy of Management Journal, 57: 1227-1234.

Indriantoro, Nur dan Supomo, Bambang. 2013. Metodologi Penelitian Bisnis Untuk Akuntansi \& Manajemen Edisi Pertama.Yogyakarta:BPFE Yogyakarta.

Jensen, Michael C. dan W.H. Meckling. (1976). Theory of The Firm: Managerial Behavior, Agency Cost and Ownership Structure. Journal of Financial Economics 3. pp:305-360.

Majid, M. Shabri Abd. 2015. Pengaruh Penerapan Manajemen Risiko terhadap Kinerja Keuangan Perbankan yang Terdaftar di Bursa Efek Indonesia.Jurnal.

Martha, W. 2014. Pengaruh Transparansi Dan Akuntabilitas Terhadap Kinerja Instansi Pemerintah Pada Dinas Di Kota Bandung (Survey diInstansi Pemerintah Kota Bandung) .Doctoral dissertation, Universitas Widyatama.

Mintara, Y. H. 2008. Pengaruh Implementasi Corporate Governance terhadap Pengungkapan Informasi.Skripsi Universitas Islam Indonesia Yogyakarta.

Moris, Richard D., 1987. "Signalling Theory and Accounting Policy Choice". Accounting and Business Research, Vol.18, No.69.

Mustikasari, E. 2015.Pengaruh Good Corpororate Governance Terhadap Kinerja Keuangan Perusahaan. Jurnal Ilmiah Mahasiswa FEB, 3(2).

Nurintan, Yara. 2016. Pengaruh Penerapan Manajemen Risiko Kredit, Risiko Pasar, Risiko Likuiditas, dan Risiko Operasional terhadap Kinerja Keuangan Perbankan (Studi pada Bank Umum Konvensional Go Public Periode 2011-

Ofo, N. 2010. Corporate Governance in Nigeria: Prospects and problems. Available at SSRN 1618600.

Ombayo, J. O. 2011. The Effect Of Corporate Governance On A Firm's Financial Performance: A Case Study Of Companies Listed On The Nairobi Stock Exchange. Doctoral dissertation, University of Nairobi, Kenya. 
Pradnyaswari, A. dan Putri IGAM, Asri Dwija. 2015. Pengaruh Prinsip-Prinsip Good Corporate Governance Pada Kinerja Keuangan Koperasi di Kabupaten Klungkung. Jurnal Fakultas Ekonomi dan Bisnis Universitas Udayana.

Purnama, S. 2016. Pengaruh Struktur Good Corporate Governance, Pengungkapan Corporate Social Responsibility dan Pertumbuhan Perusahaan pada Nilai Perusahaan Badan Usaha Milik Negara. Skripsi.Fakultas Ekonomi dan Bisnis Universitas Udayana.

Puspitasari, D. S., dan Ludigdo, U. 2014. Good Governance Koperasi Wanita Serba Usaha "Setia Budi Wanita" Jawa Timur. Jurnal Ilmiah Mahasiswa $F E B, 2(1)$.

Putri IGAM, Asri Dwija, dan Ulupui, I Gusti Ketut Agung. 2017. Pengantar Corporate Governance. Denpasar.CV Sastra Utama.

Rahmatika, N., Kirmizi, dan Agus, R. 2015. Pengaruh Penerapan Prinsip-Prinsip Good Corporate Governance Terhadap Kinerja Keuangan Perusahaan (Studi pada PT Angkasa Pura II). Jurnal Akuntansi (Media Riset Akuntansi \& Keuangan), 3(2), h:148-156.

Ratih,Suklimah. 2011. Pengaruh Good Corporate Governance Terhadap Nilai Perusahaan Dengan Kinerja Keuangan Sebagai Variabel Intervening Pada Perusahaan Peraih The Indonesia Most Trusted Company-CGPI. Jurnal Kewirausahaan, 5(2).

Riyadi, S., dan Yulianto, A. 2014. Pengaruh Pembiayaan Bagi Hasil, Pembiayaan Jual Beli, Financing To Deposit Ratio (FDR) Dan Non Performing Financing (NPF) Terhadap Profitabilitas Bank Umum Syariah Di Indonesia. Accounting Analysis Journal, 3(4).

Setyawan, K. M., dan Putri IGAM, Asri Dwija. 2013. Pengaruh Good Corporate Governance Terhadap Kinerja Keuangan Lembaga Pekreditan Desa Di Kecamatan Mengwi Kabupaten Badung.E-Jurnal Akuntansi Universitas Udayana, 5(3): h:586-598.

Shill, N. C. 2008. Accounting for Good Corporate Governance.JOAAG, 3(1).

Suci, Y. F. 2013. Pengaruh Penerapan Prinsip Good Corporate Governance Terhadap Kinerja Perusahaan Pada PT. Kereta Api (Persero) Divisi Regional III Sumatera Selatan. 
Anak Agung Gede Bagus Putra Wirawan dan I.G.A.M Asri Dwija Putri.Pengaruh...

Sudiyatno, B., dan Suroso, J. 2010. Analisis Pengaruh Dana Pihak Ketiga, BOPO,

CAR dan LDR Terhadap Kinerja Keuangan pada Sektor Perbankan yang

Go Public di Bursa Efek Indonesia (BEI)(Periode 2005-2008). Dinamika Keuangan Dan Perbankan, 2(2).

Sugiyanto. 2011. Implementasi Teori Keagenan Sebagai Dasar Memperbaiki Partisipasi Anggota Koperasi. Coopetition, 2(1).

Triyana, Y. 2012. Manfaat Penerapan Prinsip-Prinsip Good Corporate Governance Terhadap Kinerja Keuangan Perusahaan Umum Pegadaian. Doctoral dissertation, Universitas Guna.

Wibowo. 2010. Implementasi Good Corporate Governance di Indonesia. Jurnal.Fakultas Ekonomi Universitas Slamet Riyadi Surakarta.

Wijaya, I., \& Sudarma, M. 2015. Faktor-Faktor Yang Mempengaruhi Pergantian Kantor Akuntan Publik Pada Perusahaan Manufaktur Di Indonesia.Jurnal Ilmiah Mahasiswa FEB, 3(2).

Yahya, A. S. B., dan Shukeri, S. N. 2014. Corporate Governance and Firm Financial Performance for Malaysian Public Listed Company. Advances in Environmental Biology, 8(9). 